\title{
HUBUNGAN EQ (Emotional Quotient) DENGAN HASIL BELAJAR MAHASISWA BIOLOGI SEMESTER GANJIL TAHUN AJARAN 2014/2015
}

\author{
Ali Sadikin \\ Pendidikan Biologi FKIP Universitas Jambi \\ email: sadikinali35@gmail.com
}

\begin{abstract}
Emotional intelligence (Emotional Quotient) is an extra skill of an individual to motivate him or herself, to survive from a failure, to control the emotion, to hold over the comfort state of life, and to manage his or her soul. So, one of the important factors that influence the students' success in learning is the emotional intelligence. This descriptive-quantitative study was aimed to determine the relationship between emotional intelligence and the students' learning outcomes at the Basic and Process of Biology Students 2 Course of odd semester in the academic year 2014/2015. The population of the study was the third semester students. The emotional intelligence data were collected through a questionnaire in the form of statements. Data analysis techniques to determine the relationship between emotional intelligence and learning outcomes were conducted through statistical testing using simple linear regression. The results showed that the average emotional intelligence of the students obtained was 2.84 with a scale range between 2.00 to 2.99 which means that the value is low, and the emotional intelligence data frequency distribution of the students were $18.4 \%$ higher, $66.23 \%$ moderate, and $15.37 \%$ lower. Moreover, the scores of the emotional intelligence questionnaire and the students' learning outcomes formed a linear model $Y=61.03+0.133 X$. Further, the correlation analysis between the emotional intelligence and the learning outcomes showed that $r$ count have a correlation between variables $X$ and $Y$ with the value of $r$ count $=0.177$ and the scores of $t$ count $>t$ table or $2.318>1.96$ at $95 \%$ of the confidence level were indicating a significant correlation between emotional intelligence and learning outcomes.
\end{abstract}

Keyword: Emotional Intelligence and learning outcomes

\section{PENDAHULUAN}

Kecerdasan emosional telah terbukti

secara alamiah memegang peranan penting dalam mencapai keberhasilan disegala bidang, menurut Cooper dalam agustian (2005:40) hati mengaktifkan nilai-nilai kita yang terdalam, menghubungkannya dari suatu yang kita pikir menjadi suatu yang kita jalani. Hati mampu mengetahui hal-hal mana yang tidak boleh, atau tidak dapat diketahui oleh pikiran kita. Hati adalah sumber energi dan perasaan mendalam yang menuntut kita untuk melakukan pembelajaran, menciptakan kerjasama, memimpin serta melayani.

Hati nurani akan menjadi pembimbing terhadap apa yang harus ditempuh dan apa yang harus diperbuat, dalam arti kata pada dasarnya manusia itu telah memiliki radar hati sebagai pembimbingnya. Kemampuan akademik, 
nilai KHS, transkrip nilai, predikat kelulusan tinggi tidak bisa menjadi tolok ukur seberapa baik kinerja seseorang dalam pekerjaanya atau seberapa tinggi sukses yang mampu dicapai.

Pada saat ini istilah "Emotional Quotient" (EQ) atau kecerdasan emosional sudah dikenal dimasyarakat seperti halnya “Intelegensi Quotient” (IQ) atau kecerdasan intelektual (Winarno dan Tri, 2001:1). Tingkat kecerdasan intelektual ini menjadi relevan sebagai ukuran untuk melaksanakan seleksi di beberapa bidang pendidikan dan pekerjaan dan hanya yang mampu mencapai skor tertentulah yang dapat diterima. Sangat mungkin kebijakan ini diambil bukan karena mendewakan kecerdasaran intelektual itu, melainkan karena cara itulah yang secara sejarah kerap dilakukan dan paling mudah dilakukan (Niesser dkk dalam Danim, 2003:224).

Pergeseran kecenderungan yang dikemukakan oleh Neisser dkk. Tersebut dinilai sebagai paradoks yang membahayakan. Ketika kecerdasan intelektual rerata anak-anak makin meningkat alur perjalanan sejarah manusia berperadaban, bersamaan dengan itu pula kecerdasan emosional mereka justru cenderung menurun (Goleman dalam Danim, 2003:224).
Berdasarkan pada penelitian perilaku yang sangat luas, kecerdasan emosional telah menunjukkan peranan yang sangat berarti dalam kehidupan mental kita, dan bahwa sebenarnya kita memiliki dua macam pikiran yakni satu berfikir dan lainnya yang merasakan. Menurut penelitian para ahli psikologi, mereka pada umumnya sepakat bahwa IQ hanya mendukung sekitar $20 \%$ faktor-faktor yang menentukan suatu keberhasilan, sedangkan $80 \%$ lainnya adalah berasal dari faktor yang lain termasuk kecerdasan emosional (Winarno dan Tri, 2001:1).

Hasil sebuah survei terhadap orang tua dan guru membuktikan bahwa anak-anak generasi sekarang lebih sering mengalami masalah-masalah emosional dari pada generasi terdahulu. Rata-rata anak-anak sekarang tumbuh dalam kesepian dan depresi, lebih mudah marah dan lebih sulit diatur, lebih gugup, cenderung cemas, serta lebih impulsif dan agresif (Goleman dalam Danim, 2003:224).

Menurut secapramana

(1999:2) kemerosotan emosi tampak dalam semakin parahnya masalah spesifik berikut:

1. Menarik diri dari pergaulan atau masalah sosial, lebih suka menyendiri, bersikap sembunyisembunyi, banyak bermuram durja, 
kurang bersemangat, merasa tidak bahagia, terlampau tergantung.

2. Cemas dan depresi, menyendiri, sering takut dan cemas, ingin sempurna, merasa tidak dicintai, merasa gugup atau sedih dan depresi.

3. Memiliki masalah dalam hal perhatian atau berpikir: tidak mampu memusatkan perhatian atau duduk tenang, melamun, bertindak tanpa berpikir, bersikap terlalu tegang untuk berkonsentrasi, sering mendapat nilai buruk di sekolah, tidak mampu membuat pikiran menjadi tenang.

4. Nakal atau agresif; bergaul dengan anak-anak yang bermasalah, bohong dan menipu, sering bertengkar, bersikap kasar terhadap orang lain, menuntut perhatian, merusak milik orang lain, membandel disekolah dan dirumah, keras kepala dan suasana hatinya sering berubah-rubah, terlalu banyak bicara, sering mengolokolok, bertemperamen panas.

Menurut Hakim (2004:11) bahwa faktor-faktor yang mempengaruhi keberhasilan belajar adalah faktor internal dan faktor eksternal. Faktor internal terdiri dari pertama, faktor biologis (jasmaniah) seperti kondisi fisik normal atau tidak cacat, dan kondisi kesehatan fisik. Kedua, faktor psikologis (Rohaniah) seperti kecerdasan intelektual, kecerdasan emosional, kemauan, dan bakat. Sedangkan faktor eksternal meliputi faktor lingkungan keluarga, sekolah, dan masyarakat serta waktu.

Menurut Goleman (2007: 2) konsep kecerdasan dapat mempengaruhi peningkatan prestasi seseorang yaitu kecerdasan emosional . kecerdasan emosi merujuk pada kemampuan mengenali perasaan kita sendiri dan perasaan orang lain, kemampuan memotivasi diri sendiri dan kemampuan mengelola emosi dengan baik pada diri sendiri maupun pada orang lain.

Hasil wawancara penulis dengan mahasiswa di Program Studi Pendidikan Biologi FKIP Universitas Jambi tanggal 25 November 2011 menemukan bahwa mahasiswa yang memiliki permasalahan yang terkait dengan emosi yang ternyata hal itu berpengaruh terhadap hasil belajarnya. Ketika seorang mahasiswa memperoleh nilai yang rendah, ia merasa sedih, terpukul, rendah diri sehingga menimbulkan ketegangan atau kesedihan yang kemudian menghambat kemampuan belajar. Sebuah kasus lain yaitu ketika mahasiswa mengalami suatu permasalahan yang menyangkut pribadinya, kondisi hatinya 
sedang tidak nyaman, marah hal ini ternyata berpengaruh pada semangat belajarnya dan akhirnya berdampak pada menurunnya hasil belajar mahasiswa tersebut.

Sesuai dengan uraian tersebut kecerdasan emosional mahasiswa diduga berpengaruh terhadap hasil belajar. Kecerdasan emosi yang rendah akan menghambat kegiatan belajar mahasiswa itu sendiri karena ia tidak bisa memanajemen perasaanya dan menguasi emosinya. Sedangkan mahasiswa yang memiliki kecerdasan yang tinggi akan dapat mengelola dan memanfaatkan emosinya secara efektif. Ia dapat mengatasi kecemasan yang berlebihan, ketegangan atau kesedihan yang sering menghambat kemampuan belajarnya. Kesukaran dan kesulitan dalam belajar tidak membuatnya frustasi dan rendah diri tetapi membuatnya memperbaiki diri dan mencoba mengatasi kegagalankegagalan itu.

Kecerdasan emosional bukanlkah sesuatu yang statis atau bersifat genetika seperti intelegensi melainkan dapat dikembangkan dan ditingkatkan kapasitasnya. Para tenaga pendidik di sekolah maupun di perguruan tinggi dapat menciptakan iklim yang kondusif agar kemampuan mahasiswa dalam belajar dapat dioptimalkan melalui pengembangan kecerdasan emosional mahasiswanya. Berdasarkan latar belakang masalah diatas maka dilakukan penelitian dengan judul “ Hubungan EQ (Emotional Quotient) dengan Hasil Belajar Mahasiswa Biologi Semester Ganjil Tahun Ajaran 2014/2015.

\section{METODE PENELITIAN}

Penelitian ini hanya meneliti Hubungan EQ (Emotional Quotient) dengan Hasil Belajar Mahasiswa Biologi Semester Ganjil Tahun Ajaran 2014/2015 pada mata kuliah Dasar dan Proses Pembelajaran Biologi 2 di Prodi Pendidikan Biologi Juran PMIPA FKIP Universitas Jambi. Metode Penelitian yang digunakan dalam penelitian ini adalah metode penelitian deskriptif kuantitatif yang bersifat korelasional yang mencari hubungan antara dua variabel yakni kecerdasan emosional (EQ) mahasiswa dengan hasil belajar biologi mahasiswa pada mata kuliah Dasar dan Proses Pembelajaran Biologi 2 semester ganjil tahun ajaran 2014/2015 Prodi Pendidikan Biologi FKIP Universitas Jambi.

Dalam penelitian ini terdapat dua variabel yaitu variabel bebas dan variabel terikat. Variabel bebas (X) dalam penelitian ini adalah kecerdasan emosional yang meliputi kesadaran diri, pengaturan diri, kesadaran sosial dan keahlian sosial. 
Sedangkan yang menjadi variabel terikat (Y) adalah hasil belajar biologi mahasiswa. Variabel yang dikorelasikan adalah kecerdasan emosional terhadap hasil belajar biologi mahasiswa.

Populasi dalam penelitian ini adalah seluruh mahasiswa biologi semester ganjil 2014/2015 yang mengontrak mata kuliah Dasar dan Proses Pembelajaran Biologi 2 sebanyak 163 orang mahasiswa. Dalam penelilitian ini yang ditetapkan menjadi sampel adalah seluruh mahasiswa biologi semester ganjil 2014/2015 yang mengontrak mata kuliah Dasar dan Proses Pembelajaran Biologi 2 sebanyak 163 orang mahasiswa yang menjadi populasi atau disebut total sampling, sehingga penelitian ini merupakan penelitian populasi. Dalam penelitian ini adapun alat untuk mengumpulkan data adalah dalam bentuk angket. Angket yang diberikan menyoroti tentang kecerdasan emosional mahasiswa. Angket dalam penelitian ini merupakan angket tertutup yaitu angket dengan skala dan jenis jawaban yang telah ditentukan.

\section{Teknik Analisis Data}

Data yang telah diperoleh dari angket mengenai kecerdasan emosional mahasiswa ditabulasikan. Setelah data ditabulasi, selanjutnya memberikan skor pada setiap item dari masing-masing deskriptor.
Penentuan skor dilakukan menurut skala likert dengan kriteria selalu (skor 4), sering (skor 3), jarang (skor 20 dan tidak pernah (skor 1). Setelah diperoleh jumlah nilai dari angket maka dicari rata-rata yang menunjukkan hasil mengenai kecerdasan emosional siswa, apakah tergolong sangat tinggi, tinggi, cukup tinggi, rendah, dan sangat rendah. Digunakan statistik deskriptif (Sudjana, 1992) sebagai berikut:

$$
\bar{X}=\frac{\sum f i \cdot X i}{\sum f i}
$$

Keterangan :

$\bar{X}=$ Rata-rata jawabanF

$f i=$ Frekuensi jawaban

$\mathrm{Xi}=$ Jumlah sampel

Dengan rentangan nilai sebagai berikut :

Skala 1,00-1,99 = berarti sangat rendah

Skala 2,00-2,99 = berarti rendah

Skala 3,00-3,99= berarti cukup tinggi

Skala 4,00-4,99 = berarti tinggi

Skala $>4,99=$ berarti sangat tinggi

Kemudian untuk mengetahui hubungan variabel bebas (X) yaitu kecerdasan emosional mahasiswa dengan variabel terikat (Y) hasil belajar mahasiswa pada bidang studi biologi, dianalisis dengan menggunakan regresi linear sederhana. Adapun yang harus dipenuhi sebelum regresi digunakan adalah data berdistribusi normal dan berpola linier. 


\section{a. Uji Normalitas}

Uji normalitas digunakan untuk mengetahui apakah data angket dan data hasil belajar sampel penelitian berdistribusi normal. Dalam penelitian ini digunakan uji lilliefors. Menurut Sudjana (1992:466). Langkah-langkah uji Lilliefors sebagai berikut :

1. Membuat tabulasi data.

2. Mengadakan pengamatan terhadap $X_{1}$,

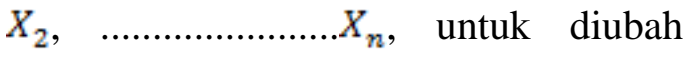
menjadi angka baku $Z_{1}, \quad Z_{2}$, ............. $Z_{n}$, dengan rumus :

$$
Z_{i}=\frac{X_{i}-X}{S}
$$

Keterangan :

$Z_{i}=$ Angka baku

$\mathrm{X}=$ Rata-rata

$\mathrm{S}=$ Simpangan Baku

3. Menentukan peluang $\mathrm{F}\left(Z_{i}\right)=\mathrm{P} \leq\left(Z_{i}\right)$

berdasarkan daftar distribusi normal baku.

4. Selanjutnya dihitung proposi $Z_{1}, Z_{2}$, $Z_{n}$, yang lebih kecil atau sama dengan Z. Jika proporsi ini dinyatakan oleh $\mathrm{S}\left(Z_{i}\right)$ dengan rumus :

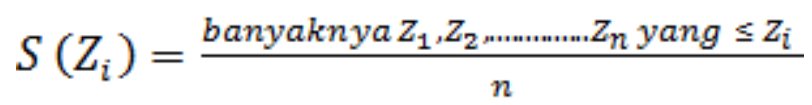

5. Harga mutlak dihitung dari selisih $\mathrm{F}\left(Z_{i}\right)-S\left(Z_{i}\right)$ dan diambil dari harga mutlak yang paling besar sebagai Lhitung $\left(L_{0}\right)$.

6. Dicari L-tabel $\left(L_{t}\right)$ untuk sebanyak $\mathrm{n}$ dengan taraf nyata $\alpha=0,05$, dan dibandingkan dengan $L_{0}$.

7. Pada taraf nyata $\alpha=0,05$, jika $L_{0<} L_{t}$ maka tabel terdistribusi normal dan jika sebaliknya sampel terdistribusi tidak normal.

\section{b. Uji Linieritas}

Uji linieritas regresi dilakukan untuk mengetahui bentuk hubungan antara variabel $\mathrm{X}$ dengan variabel $\mathrm{Y}$, apakah linier atau tidak. Dalam penelitian ini digunakan persamaan sederhana sebagai berikut :

$$
\mathrm{Y}=\mathrm{a}+\mathrm{Bx}
$$

Dengan

$\mathrm{a}=\frac{\left(\sum Y\right)\left(\sum X^{2}\right)-\left(\sum X\right)\left(\sum X Y\right)}{n \sum X^{2}-\left(\sum X\right)^{2}}$ 
$\mathrm{b}=\frac{n \sum X Y-\left(\sum X\right)\left(\sum X Y\right)}{n \sum X^{2}-\left(\sum X\right)^{2}}$

Keterangan :

$\mathrm{Y}=$ Variabel terikat berupa hasil belajar

$\mathrm{X}=$ Variabel bebas berupa kecerdasan emosional

$\mathrm{a}, \mathrm{b}=$ koefisien regresi

$\mathrm{n}=$ ukuran sampel (Sudjana, 1992:12).

Setelah harga Y didapat, kemudian
Untuk mengetahui apakah bentuk linear bentuk-bentuk cocok dengan keadaan atau tidak. Analisis varians yang dilakukan untuk menghitung jumlah kuadrat (JK) yang disebut sumber varians. Semua besaran yang diperoleh, disusun dalam daftar anava yang dapat dilihat pada tabel 3.2 berikut :

dilakukan uji linieritas dengan varians.

Tabel 3.2 Analisis Varians untuk uji kelinieran regresi

\begin{tabular}{|c|c|c|c|c|}
\hline Sumber Varians & DK & JK & JKT & \\
\hline Total & $\mathbf{N}$ & $Y^{2}$ & $Y^{2}$ & \\
\hline $\begin{array}{l}\text { Koefisien (a) } \\
\text { Regresi (b/a) } \\
\text { Residu }\end{array}$ & $\begin{array}{l}1 \\
1 \\
n-2\end{array}$ & $\begin{array}{l}\text { JK (a) } \\
\text { JK (b/a) } \\
\text { JKreg }\end{array}$ & $\begin{array}{l}\mathrm{JK}(\mathrm{a}) \\
S^{2} \mathrm{reg}=\mathrm{JK}(\mathrm{b} / \mathrm{a}) \\
S^{2} \text { res }=\frac{J \text { Kres }}{n-2}\end{array}$ & $\frac{S^{2} \text { reg }}{S^{2} \text { res }}$ \\
\hline $\begin{array}{l}\text { Tuna cocok } \\
\text { Galat }\end{array}$ & $\begin{array}{l}\mathrm{K}-2 \\
\mathrm{n}-\mathrm{k}\end{array}$ & $\begin{array}{l}\mathrm{JK}(\mathrm{TC}) \\
\mathrm{JK}(\mathrm{E})\end{array}$ & $\begin{array}{l}S^{2}(T C)=\frac{J K(T C)}{K-2} \\
S^{2} e=\frac{J K(E)}{K-2}\end{array}$ & $\frac{S^{2} \mathrm{TC}}{S^{2} \mathrm{e}}$ \\
\hline
\end{tabular}

Sudjana (1992:32)

Dari tabel 3.2 didapat dua hasil, yaitu :

Untuk menentukan uji linier, terima

1) $\mathrm{F}=S^{2}$ reg $/ S^{2}$ res untuk uji

model $T_{\text {hitung }} \leq T_{\text {tabel }} \quad(1-\alpha)(\mathrm{k}-2, \mathrm{n}-\mathrm{k})$

kelayakan regresi.

(Sudjana, 1992:332).

2) $\mathrm{F}=S^{2} \mathrm{TC} / S^{2} \mathrm{G}$ untuk menentukan

apakah data berpola linier atau tidak.

\section{c. Uji Hipotesis}

Hipotesis dalam penelitian ini adalah terdapat hubungan antara kecerdasan emosional dengan hasil belajar mahasiswa 
semester IV tahun pelajaran 2011/2012. Untuk menguji hipotesis ini digunakan rumus korelasi product moment dengan rumus sebagai berikut :

$$
r=\frac{n \sum X Y-\left(\sum X\right)\left(\sum Y\right)}{\sqrt{\left.\left[n \sum X^{2}-\left(\sum X^{2}\right)\right\} n \sum Y^{2}-\left(\sum Y^{2}\right)\right]}}
$$

Keterangan :

$\mathrm{r} \quad=$ Koefesien korelasi

$\mathrm{n}=$ Jumlah sampel

$\mathrm{X}=$ Jumlah skor dalam variabel bebas $(\mathrm{X})$

$\mathrm{Y}=$ Jumlah skor dalam variabel terikat $(\mathrm{Y})$

Korelasi PPM dilambangkan (r) dengan ketentuan nilai $r$ tidak lebih dari harga $(-1 \leq 0 \leq+1)$. Apabila $r=-1$ artinya korelasi negatif sempurna; $r=0$ artinya tidak ada korelasi; dan $\mathrm{r}=1$ berarti korelasinya sangat kuat. Sedangkan arti harga $r$ akan dikonsultasikan dengan tabel interprestasi nilai $\mathrm{r}$ sebagai berikut :

Tabel 3.3 Kriteria Penafsiran Indeks

Korelasi (r)

\begin{tabular}{|l|l|}
\hline \multicolumn{1}{|c|}{ Besar } & Tingkat hubungan \\
\hline $0,00-0,199$ & Sangat rendah \\
$0,20-0,399$ & Rendah \\
$0,40-0,599$ & Sedang \\
$0,60-0,799$ & Kuat \\
$0,80-1,000$ & Sangat kuat \\
\hline
\end{tabular}

Selanjutnya untuk menyatakan besar kecilnya sumbangan variabel $\mathrm{X}$ terhadap variabel Y dapat ditentukan dengan rumus koefesien determinan (R) sebagai berikut :

$R=r^{2} \times 100 \%$

Keterangan :

$\mathrm{R}=$ koefisien determinasi

$\mathrm{r}=$ koefisien korelasi

Untuk mencari makna hubungan variabel $\mathrm{X}$ terhadap variabel $\mathrm{Y}$, maka hasil korelasi PPM diuji dengan uji signifikansi dengan rumus sebagai berikut :

$t_{\text {hitung }}=\frac{\sqrt[r]{n-2}}{\sqrt{n-r^{2}}}$

Keterangan :

$t_{\text {hitung }}=$ nilai $\mathrm{T}$

$\mathrm{R}=$ Nilai koefisien korelasi

$\mathrm{N} \quad=$ Jumlah sampel

(Ridwan, 2004: 137)

\section{HASIL DAN PEMBAHASAN}

Dari hasil penyebaran angket, setelah data ditabulasi dan dianalisis denga statistic deskriptif, maka diketahui bahwa kecerdasan emosional (EQ) mahasiswa semester Ganjil 2014/2015 yang mengontrak mata kuliah Dasar dan Proses Pembelajran Biologi 2 rata-rata 2,84 tergolong rendah. Skala rentangan nilai antara 2,00-2,99 yang menunjukkan bahwa kecerdasan emosional mahasiswa rendah. Meskipun ada beberapa mahasiswa yang menunjukkan kecerdasan emosional yang cukup tinggi, namun secara 
keseluruhan tergolong rendah. Hal ini tentu masih perlu ditingkatkan agar siswa mempunyai kecerdasan emosional yang tinggi. Menurut Patto dalam Uno (2006:70) tinggi rendahnya kecerdasan emosional seseorang dapat disempurnakan dengan kesungguhan, pelatihan dan kemauan. Dari 163 orang mahasiswa 30 orang mahasiswa $(18,4 \%)$ memiliki kecerdasan emosional tingggi, 108 orang mahasiswa $(66,23 \%)$ memiliki kecerdasan emosional sedang dan 25 orang mahasiswa $(15,37 \%)$ memiliki kecerdasan emosional rendah.

Dari 163 orang mahasiswa 35 orang $(21,47 \%)$ memiliki hasil belajar biologi yang tinggi, 98 orang mahasiswa $(60,12 \%)$ memiliki hasil belajar biologi sedang, dan 30 orang mahasiswa $(18,41)$ memiliki hasil belajar yang rendah. Dari hasil perhitungan data variabel $\mathrm{x}$ (kecerdasan emosional mahasiswa) diperoleh nilai $L_{0}=0,0540$

dengan $n=163$ dalam daftar nilai kritis untuk uji liliefors pada taraf kepercayaan 95\%, diperoleh $L_{t}=0,0694$, maka $L_{0}<L_{t}$.

Dengan demikian dapat dikatakan data skor variabel $\mathrm{X}$ berdistribusi normal.
Dari hasil perhitungan normalitas data variabel Y (Hasil belajar biologi mahasiswa) diperoleh nilai $L_{0}=0,0645$ dengan $n=163$ dalam daftar kritis untuk uji liliefors pada taraf kepercayaan 95\% di dapat $L_{t}=0,0694$ maka $L_{0}<L_{t}$. Dengan

demikian dapat dikatakan data skor variabel Y berdistribusi normal.

Untuk mengetahui apakah bentuk hubungan antara variabel $\mathrm{X}$ dan $\mathrm{Y}$ linear atau tidak, dilakukan dengan uji linieritas. Dalam penelitian ini digunakan persamaan regresi sederhana $\mathrm{Y}=\mathrm{a}+\mathrm{bX}$. Setelah dilakukan perhitungan diperoleh nila $a=61,03$ dan nilai $b=0,133$, sehingga persamaan regresinya menjadi $\mathrm{Y}=61,03+0,133 \mathrm{X}$. setelah harga $\mathrm{Y}$ didapat, maka dilakukan uji lineiritas dengan varians, untuk mengetahui apakah betuk linier batulbetul cocok dengan keadaan atau tidak. Analisis varians dilakukan untuk menghitung jumlah kuadrat (JK) yang disebut dengan sumber variansi. Semua besaran yang diperoleh disusun dalam daftar anava yang dapat dilihat pada table berikut: 


\begin{tabular}{|l|l|l|l|l|l|}
\hline Sumber varians & $\begin{array}{c}\text { Derajat } \\
\text { kebebasan } \\
(\mathrm{dk})\end{array}$ & $\begin{array}{c}\text { Jumlah kuadrat } \\
(\mathrm{JK})\end{array}$ & $\begin{array}{c}\text { Rata-rata } \\
\text { jumlah } \\
\text { Kuadrat (RJK) }\end{array}$ & $F_{\text {hitung }}$ & $F_{\text {tabel }}$ \\
\hline Total & 163 & & & & \\
\hline Regresi (a) & 1 & 962734,53 & 962734,53 & 5,24 & 3,91 \\
Regresi (b/a) & 1 & 444,299 & 444,299 & & \\
Residu & 161 & 13634,171 & 84,68 & 1,48 \\
\hline Tuna cocok & 49 & 4822,715 & 98,42 & 1,25 & 78,67 \\
Galat & 112 & 8811,456 & 78,6 & & \\
\hline
\end{tabular}

Dari table ternyata diperoleh $F_{\text {hitung }}=1,25$ dengan $\alpha=0,05 \mathrm{dk}$ pembilang

49 dan dk penyebut 112 diperoleh $F_{\text {tabel }}=1,48$. Jadi $F_{\text {hitung }}<F_{\text {tabel }}$ atau

$1,25<1,48$. Maka dengan demikian dapat dikatakan bahwa persamaan regresi variabel $\mathrm{X}$ dan $\mathrm{Y}$ mempunyai model yang linier. Setelah diperoleh data yang berpola linier selanjutnya dilakukan uji kelayakan regresi. $F_{\text {hitung }}$ yang diperoleh adalah sebesar 5,24.

Sementara dari table distribusi $\mathrm{F}$ untuk $\alpha=0,05$ dengan $\mathrm{dk}$ pembilang $1 \mathrm{dan} \mathrm{dk}$ penyebut 161 diperoleh $\quad F_{\text {tabel }}=3,91$.

Dengan demikian $F_{\text {hitung }}<F_{\text {tabel }}$ maka

persamaan yang dikemukakan berarti.

Berdasaran analisis yang telah dilakukan, dari hasil uji linieritas dan keberartian regresi yang terbentuk, ternyata berbentuk linier, hal ini menunjukkan bahwa kecerdasan emosional mempunyai hubungan dengan hasil belajar biologi mahasiswa. Menurut Slameto (1987:114) kecerdasan emosional akan berpengaruh terhadap hasil belajar. Kecerdasan emosional merupakan kemampuan mengenali, dan mengelola emosi, memotivasi diri, mengenali emosi orang lain serta melakukan suatu hubungan yang baik. Menata emosi sebagai alat untuk mencapai tujuan adalah hal yang penting dalam kaitan untuk memberi perhatian, memotivasi dan menguasai diri sendiri, keberhasilan pencapaian prestasi juga didasarkan pada kemapuan emosional sehingga siswa dapat mencapai prestasi belajar secara optimal (Hidayah:2003).

Dari hasil pengujian hipotesis memperlihatkan korelasi yang signifikan antara kecerdasan emosional mahasiswa dengan hasil belajar biologi pada mata kuliah Dasar dan Proses Pembelajaran Biologi 2. Dengan perolehan nilai $t_{\text {hitung }}=2,318$ sedangkan $t_{\text {tabel }}$ dengan $\mathrm{n}=163-2$ untuk $\alpha=0,05$ adalah 1,96 dengan 
demikian $t_{\text {hitung }}>t_{\text {tabel }}$ atau 2,318>1,96

maka dapat disimpulkan terdapat korelasi yang signifikan antara kecerdasan emosional mahasiswa dengan hasil belajar biologi pada mata kuliah Dasar dan Proses Pembelajaran Biologi, dimana semakin tinggi kecerdasan emosional maka semakin tinggi hasil belajar biologi mahasiswa.

Untuk melihat persentase hubungan antara variabel $\mathrm{X}$ terhadap variabel $\mathrm{Y}$ digunakan rumus determinasi ( $\mathrm{R}$ ) dimana $R=r^{2} \times 100 \%$. Harga $\mathrm{r}$ yang dimaksud adalah $r_{\text {hitung }}=0,177$, maka akan diperoleh harga $R=3,13 \%$. Harga $R$ yang diperoleh menunjukkan bahwa hasil belajar biologi mempunyai hubungan dengan kecerdasan emosional sebesar 3,13\%. Kontribusi kecerdasan emosional terhadap hasil belajar biologi adalah 3,13\%. Angka ini menunjukkan bahwa 3,13\% dari variasi nilai biologi dipengaruhi oleh kecerdasan emosional sedangkan 96,87\% dipengaruhi oleh factor lain yang mempunyai hubungan dengan hasil belajar mahasiswa yang tidak diukur dalam penelitian ini. Menurut Altaria (2007:1) keberhasilan belajar dipengaruhi oleh banyak factor yang bersumber dari dalam diri maupun dari luar diri individu. Factor internal meliputi keadaan fisik secara umum. Sedangkan psikologi meliputi variabel kognitif termasuk didalamnya adalah kemampuan khusus atau bakat dan kemampuan umum atau intelegensi. Variabel kognitif adalah minat, motivasi, dan variabel kepribadian. Factor eksternal meliputi aspek social, kondisi tempat belajar, sarana dan perlengkapan belajar, materi pelajaran dan kondisi lingkungan. Menurut Hakim (2004:11) bahwa factor yang mempengaruhi belajar adalah factor internal yang meliputi factor biologis, factor psikologis (intelegensi, kemauan, bakat, motivasi, dan daya ingat). Factor eksternal meliputi lingkungan keluarga, sekolah, masyarakat, dan waktu).

\section{KESIMPULAN}

Berdasarkan hasil penelitian dan pembahasan tentang kecerdasan emosional dan hubungannya dengan hasil belajar biologi pada mata kuliah Dasar dan Proses Pembelajaran Biologi 2 maka dapat disimpulkan bahwa:

1. Tingkat kecerdasan emosional mahasiswa semester Ganjil 2014/2015 Prodi Pendidikan Biologi FKIP Universitas Jambi termasuk kategori rendah.

2. Terdapat korelasi yang signifikan antara kecerdasan emosional 
(EQ/Emotioanl Quotient) dengan hasil belajar biologi mahasiswa semester Ganjil 2014/2015 Prodi Pendidikan Biologi FKIP Universitas Jambi.

3. Kontribusi kecerdasan emosional (Variabel X) terhadap hasil belajar biologi (Variabel Y) sebesar 3,13\%. Angka ini menunjukkan bahwa $3,13 \%$ dari variasi nilai dipengaruhi oleh kecerdasan emosional sedangkan 96,87\% dipengaruhi oleh factor-faktor lain. Baik yang berasal ari dalam diri (internal) mahasiswa maupun yang berasal dari luar (eksternal) diri mahasiswa.

\section{DAFTAR RUJUKAN}

Agustian, A. G. 2005, Rahasia Sukses Membangun Kecerdasan Emosi dan Spritual. Jakrta : Arga.

Altaria, V. 2007. Intelegensi Vs Prestasi Belajar. Jakarta : Rineka Cipta.

Arikunto, S. 2002. Prosedur Penelitian. Revisi V. Jakarta : Rineka Cipta.

Goleman, D. 2002. Kecerdasan Emosional. Jakarta : PT. Gramedia Pustaka Utama.

Hakim, T. 2004. Belajar Secara Efektif. Jakrta : Puspa Swara.

Hariwijaya, M. 2005. Tes Kecerdasan Emosional (EQ). Yogyakarta : Pustaka Pelajar.

Mu'tadin, Z. 2002. Mengenal Kecerdasan Emosional Remaja. Jakarta : PT. Gramedia Pustaka Utama.

Riduwan. 2004. Metode dan Teknik Menyusun Tesis. Bandung ; Alfabeta.

Slameto. 2010. Belajar dan Faktor-faktor yang Mempengaruhinya. Jakarta : Rineka Cipta.

Sugiyono. 2006. Metode Penelitian Kuantitatif, Kualitatif dan $R \& D$. Bandung : Alfabeta.

Sudjana. 1992. Metode Statistika. Bandung : Tarsito.

Uno, H.B. 2006. Orientasi Baru dalam Psikologi Pembelajaran. Jakarta : Bumi Aksara.

Winarno dan Tri, S. 2001. Kecerdasan Emosional Bahan Ajar DIKLATPIM Tingkat IV. Jakarta : Lembaga Administrasi Negara RI. 